\title{
The Commonality and Peculiarity of Western and Eastern Social Protection System
}

\author{
Nabiyev Farkhod, Ja`farkhan Isakhanov \\ Department of Social Sciences, Faculty of Psychology and Social Sciences, Samarkand State University, Samarkand City, Uzbekistan \\ Email address: \\ student_0714@mail.ru (J. Isakhanov) \\ To cite this article: \\ Nabiyev Farkhod, Ja farkhan Isakhanov. The Commonality and Peculiarity of Western and Eastern Social Protection System. International \\ and Public Affairs. Vol. 2, No. 3, 2018, pp. 62-65. doi: 10.11648/j.ipa.20180203.12
}

Received: October 24, 2018; Accepted: November 7, 2018; Published: December 4, 2018

\begin{abstract}
Social protection is a priority in the republic of Uzbekistan to implement socially-oriented market relations. This can be seen in the fact that one of the five principles of the Uzbek model of development is a strong social policy. As human society has emerged, people who need social protection have been formed. The social protection system has been developed and improved in a long evolutionary process. Every period has had its own social problems and the social protection system as well. Nowadays, social protection issues have global nature like many other issues. The globalization of some areas of social life, first of all, globalization of economic sphere, cultural sphere and even political globalization has started the integration process in social protection system. Nowadays, globalization of issues related to social protection system requires global measures to be taken. Global measures require humanity to be united. The threat of global problems that bring the humanity into the collapse urges people to unite. In order to unite, instead of differences, the commonality of people should be paid attention.
\end{abstract}

Keywords: Socially-Oriented Market, Social Protection System, Economic Sphere, Social Integration, Individualism, Communist Ideology

\section{Introduction}

The President of the Republic of Uzbekistan SH. M. Mirziyoyev emphasized the fact that the priority task is to strengthen the social protection of the people and families and to bring up the mature generation and developed "The strategy of actions on five main priorities of developing the Republic of Uzbekistan in 2017-2021". According to the strategy of actions, it is for producing mature and happy generation. Mature generation can be grown and shaped on the basis of national and humanitarian values.

Improvement of the social protection system and increasing the effectiveness requires integration of the protection of vulnerable population. Social integration, in its turn, requires development of a joint strategy.

This can be seen from the measures taken in recent years by the results of international forums and conferences held in our country. But in the process of globalization and integration we should not forget about the essence of the East and the West. The Nobel Prize laureate, British writer, J. Kipling said: "The West is the West and the East is the East and they cannot be merged until the end of the world"[2]. His words should be remembered but today his opinion has become old. There should be mentioned opinions that say Eastern and western nations can live and work together.

Certainly, researches should value the rich experience of the developed countries of the world and use it creatively in our development. Only we should use it with creative approach based on our mentality and stereotype. It is not appropriate to simply take and implement the historical experience of the Western countries into the Eastern ones. Because, the individualism of the West and the public values of the East require a careful attitude to democracy. To understand this, researches should consider the characteristics of the Eastern and the Western families. In Western families the relationship between parents and children is based on equality. In the East, parents take the priority and even looking directly at the eyes can be considered as disrespect for children. In the western family, it is normal for a child to speak to his parents in a rugged way. Famous French philosopher, Fredick Le Plein wrote: "in order to understand the society it is necessary to understand 
the family" [3].

In today's globalization and regional integration, the development of a collaborative strategy for integrating the social protection system with the national and global values is a requirement. Of course, social security issues are essentially the same for all, regardless of their nationality, religion, race, or geographical location. The basic needs of all people, such as food, clothing, and shelter, are the same. However, the ways and methods of social protection can vary from one country to another, depending on the actual conditions and mentality in that country. Social protection is defined by the complexity of the social problem [6].

\section{Materials and Methods}

Nowadays, the most vulnerable population is the result of the global crisis of families. The global crisis of the family is evident in unmarried families, divorces, single family marriages, homosexual and lesbianism. This crisis is being considered by experts as crucial as the threat of nuclear weapon, terrorism and ecological problems. All of the global problems, no matter together they are or individually, considered destructive for the humankind. Because the crisis of the family means the dysfunction of it. Functions of the family consist of reproductive, existential and social functioning that ensures the survival of life. In other words, the family gives life to the child, raises and prepares him for life. For thousands of years, the family has fulfilled its functions and ensures the next existence of mankind. But nowadays, this has become problem [7].

The global crisis of the family is not going the same in the Western and the Eastern countries. The crisis is mostly strong in the Western countries. And in Eastern families it is relatively soft. One of the reasons is the diversity in the level of the development of the spirituality of the nation in the formation of civil society [8]. The formation of civil society in the Western countries has begun rather early. In this process, as the rights of the citizens have been improved and they started to act in more liberal way, citizens began to diverge from the right path. Because, if the rights increase, people start to feel free and do not realize their divergence. This process slowly takes place over many years.

In order to act in a right way and to maintain the order in society, humanity has composed two social regulators - the rights and morals. In the case of the formation of a civil society, the possibility of legal influence is lessened, and the second social regulator, the morals must be strengthened and replaced. In the Western countries, they did not know this beforehand, and in the process of civil society formation, they did not pay enough attention to protect social morality and raising their morale. Moreover, in western countries, based on individualism, the need for spirituality was not high. Not focusing on spirituality has resulted in a number of global issues that have brought humanity to ruin, including the global crisis of the family [13].

\section{Discussion}

As the global crisis of the family is at different levels in the West and in the East, the outcomes are in varying degrees as well. In the Western countries, the global crisis of the family has grown so intensely that, in some cases they see it as a modern family, not a crisis. So, they are not focusing on consolidating the families but trying to protect children, young people and the elderly separately from the family. In other words, they try to solve the problem without eliminating the cause. But solving the problem in this way is impossible [12]. Because, the humanity has a problem as long as there is a reason for it. That is why, instead of imitating them, researches should implement the protection of children, young people and the elderly by consolidating the family. Because researches are at the forefront of civil society development and the global crisis of the family is in its beginning stage.

In other words, as the treatment of the disease should be based on the level of illness, the measures should be taken according to the level of the family's global crisis. In fact, Western countries should focus on strengthening the family as well. Because, the social protection of children, young people and the elderly can not be effective without strengthening the family. Famous Ibn Sino did not say "the cause of the disease is to be treated, not the disease itself" for no reason. In today's condition, the reason is the global crisis of the family [4]. For this reason, a strategy for social protection between the countries of the West and the East should be aimed at integrating a vulnerable population into the family. People must live with family protection from coming into this world until leaving it [11].

Analyzing the social protection issues in terms of cause and effect indicates that the increase in the number of vulnerable population who need social protection is actually a result of global family crisis [10]. The global crisis of the family is a consequence of the fact that in the formation of civil society, the morale was not protected properly and therefore, the sense of spirituality became poor. The decrease of the spirituality in the Eastern countries, especially in the former Soviet Union was caused by communist ideology and atheistic education. Because, in the Soviet period people started to forget about national and religious values and therefore faced the moral weakening. Only after the independence, there was an opportunity to restore the national and religious values and increase the spirituality based on them [14].

\section{Result}

The peculiarity of the West and the East, more precisely, the individualism in the West and the public values in the East resulted in different demands. The priority of public values in the East increased the demand for spirituality. Because socialism is based on the priority of the public, it creates high demand for the spirituality. In order to support public interests, it is necessary for a person to have high 
spirituality [15]. The spirituality ensures the protection of interests of others by shaping certain ethical principles in the heart of a person. A person who has high sense of spirituality has the ethical principle that thinks others' interests are more important than his own [16]. One of the main reasons of why the level of global family crisis is not the same in the West and in the East is the different degrees of spirituality. The analysis of the global crisis of the family shows that the cause of the crisis is spiritual poverty [17]. Because the level of the global family crisis is not the same, the measures to overcome it should also be appropriate [9].

Considering the fact that the global family crisis is a result of spiritual poverty, we should increase the sense of spirituality globally. In the book "High Spirituality Invincible Power" of the first President Islam Karimov, the fact that the issue of spirituality is not related to only one certain nation's global problem is mentioned and there was said: "It is either East or West, or African continent anywhere in the world, if there is a threat to spiritism, ....... This problem with major social and political significance is to be studied, analyzed and evaluated as a matter of concern to the lives of all countries and people "[5]. Therefore, it is desirable that planting good ideas in this book into the hearts and minds of people globally is one of the core elements of the cooperation between Eastern and Western countries.

The level of development of the social sphere system is the main criterion when evaluating the level of development of each country by the international community. Further improvement of the system of social protection in Uzbekistan is desirable to establish a special center for coordinating state and non-governmental organizations in this area.

\section{Conclusion}

In summary, it should be said that in today's complicated globalization, the global problems facing human society, both the global crisis of the family and the social problems that arise as a result of this crisis, are also directly related to the problems of spirituality. Overcome the global family crisis that put the further existence of the humanity requires global measures. For this purpose it is necessary to establish a special international coordinating center for cooperation in the field of social protection between the countries of the West and the East. This center serves to overcome the global family crisis by increasing the sense of spirituality in a global scale.

The Center for the Coordination of the Social Protection System of our Republic and international community should focus on bringing the family out of the crisis and strengthening its social security, namely social protection for children, young people and the elderly.

For this purpose, it is desirable to create a symbol of tolerance that promotes unity of mankind. It should be noted that humanity has a common characteristics regardless of their nation, religion, race and geographical location. The symbol should be created that shows that although there are many religions, the Allah is single and regardless of many races and nations, all people are descended from Adam and Eve.

We offer the symbol of ethnic and religious tolerance in Uzbek and English in the following:

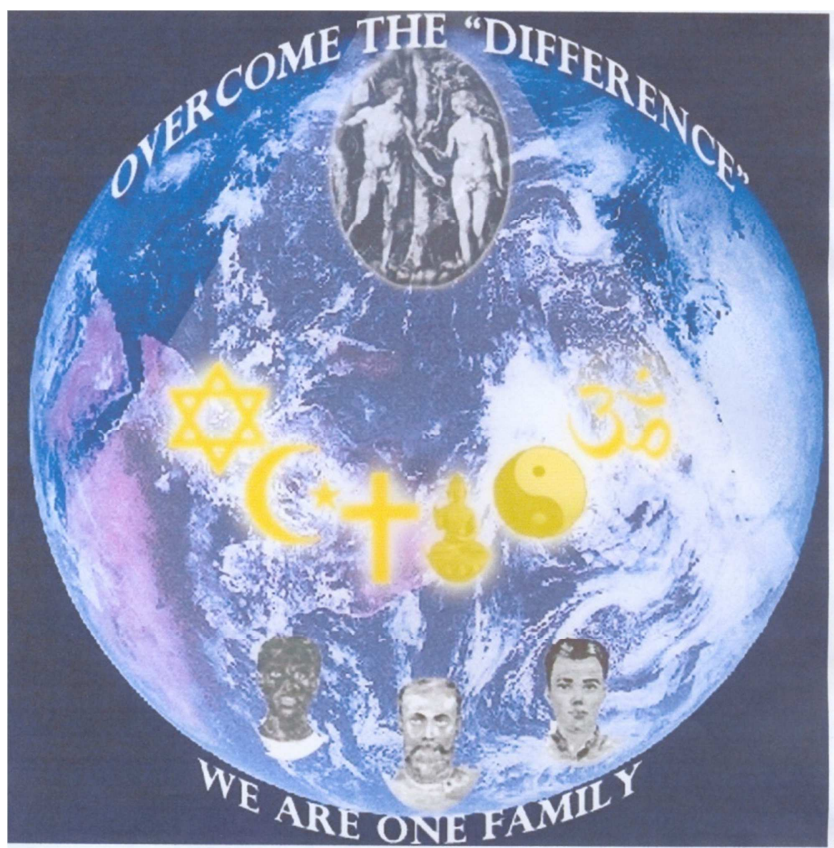

Figure 1. Basics of ethnic and religious tolerance.

Spreading the ideas of tolerance in this emblem and educating people serves to unite the humanity globally. Uniting is inseparable part of resolving the global issues such as the global family crisis by strengthening the social protection (figure1).

\section{References}

[1] Mirziyoyev Sh. M. Strategy for Actions on five priority areas for the development of Uzbekistan in the years 2017-2021, the Center of Strategy Development. Tashkent-2017.

[2] Islam Karimov. High spirituality-invincible force. Tashkent, Ma'naviyat, 2008.

[3] Sugimoto CR, Work S, Larivière V, Haustein S. Scholarly use of social media and altmetrics: A review of the literature. J Assoc Inf Sci Technol. 2017.

[4] Van Noorden R. Online collaboration: Scientists and the social network. Nat News. 2014.

[5] United Nations Research Institute for Social Development (UNRISD). 2010. Combating Poverty and Inequality: Structural Change, Social Policy and Politics.

[6] United Nations Research Institute for Social Development (UNRISD). 2010. Combati ng Poverty and Inequality: Structural Change, Social Policy and Politics.

[7] Betcherman, G., Olivas, K. and Dar, A., 2004, 'Impacts of Active Labor Market Programs: New Evidence from Evaluations with Particular Attention to Developing and Transition Countries', Social Protection Discussion Paper Series no. 0402, World Bank, Washington. 
[8] Governance and Social Development Resource Centre. [Date accessed October 31, 2010].

[9] Lund, F., 2009, 'Social Protection and the Informal Economy: Linkages and Good Practices for Poverty Reduction and Empowerment', in Organisation for Economic Cooperation and Development (OECD), 'Promoting Pro-Poor Growth: Social Protection', OECD, Paris.

[10] Howell, F., 2001, 'Social Assistance - Theoretical Background', in 'Social Protection in the Asia and Pacific', ed. I. Ortiz, Asian Development Bank, Manila.

[11] Kwon, Huck-Ju. 2009. "The reform of the developmental welfare state in East Asia". International Journal of Social Welfare. Volume 18, pages S12-S21, April 2009.

[12] Cook, S. and Kabeer, N., 2009, 'Socio-economic Security over the Life Course: A Global Review of Social Protection', Institute of Development Studies, Brighton.

[13] The World Bank. Social Protection. [Date accessed October $31,2010]$.

[14] Cook, S. and Kabeer, N., 2009, 'Socio-economic Security over the Life Course: A Global Review of Social Protection', Institute of Development Studies, Brighton.

[15] Spicker, Paul. "An introduction to Social Policy". www2.rgu.ac.uk. Retrieved 21 May 2015.

[16] "LABEL SPOTLIGHT - SOCIAL FAMILY RECORDS". www.air.org.au. 7 July 2013. Retrieved 10 May 2016.

[17] Journals Ranked by Impact: Sociology". 2017 Journal Citation Reports. Web of Science (Social Sciences ed.). Thomson Reuters. 2018. 